\title{
Adult Plant Evaluation of Soybean Accessions for Resistance to Phakopsora pachyrhizi in the Field and Greenhouse in Paraguay
}

\author{
M. R. Miles, USDA-ARS, National Soybean Research Center, University of Illinois, Urbana 61801; W. Morel, \\ Centro Regional de Investigación Agrícola, Capitán Miranda, Itapúa, Paraguay; J. D. Ray, USDA-ARS, Crop Genet- \\ ics and Production Research Unit, Stoneville, MS 38776; J. R. Smith, USDA-ARS, Crop Genetics and Production \\ Research Unit, Stoneville, MS 38776; R. D. Frederick, Foreign Disease-Weed Science Research Unit, USDA-ARS, \\ Ft. Detrick, MD 21702; and G. L. Hartman, USDA-ARS, National Soybean Research Center, Department of Crop \\ Sciences, University of Illinois, Urbana 61801
}

\begin{abstract}
Miles, M. R., Morel, W., Ray, J. D., Smith, J. R., Frederick, R. D., and Hartman, G. L. 2008. Adult plant evaluation of soybean accessions for resistance to Phakopsora pachyrhizi in the field and greenhouse in Paraguay. Plant Dis. 92:96-105.

Five hundred thirty soybean accessions from maturity groups (MG) III through IX were evaluated for resistance to Phakopsora pachyrhizi in a replicated field trial at Centro Regional de Investigación Agrícola in Capitán Miranda, Itapúa, Paraguay during the 2005-06 season. Soybean rust severities of individual accessions ranged from $0 \%$ (resistant) to $30.0 \%$ (susceptible). In MG III and IV, the most resistant accessions were PI 506863, PI 567341, and PI 567351B, with severities less than $1.2 \%$. In MG V, the most resistant accessions were PI 181456, PI 398288, PI 404134B, and PI 507305, with severities less than 0.3\%. In MG VI, the most resistant accessions were PI 587886, PI 587880A, and PI 587880B, with severities less than $0.3 \%$. In MG VII and VIII, the most resistant were PI 587905 and PI 605779E, with severities less than 1.0\%. In MG IX, the most resistant accessions were PI 594754, PI 605833, PI 576102B, and PI 567104B, with severities less than $1.0 \%$. The resistance in 10 selected accessions from MG VI, VII, VIII, and XI was confirmed in subsequent greenhouse and field experiments where severities of $0.4 \%$ or less and reddish-brown lesions with sporulation levels less than 3.0 were observed. These accessions, with low severities in the adult plant field evaluation, may be new sources of resistance to $P$. pachyrhizi.
\end{abstract}

Phakopsora pachyrhizi (H. Sydow \& Sydow), the causal fungus of soybean rust, was discovered in Paraguay in 2001 (16) and has since spread through most of the soybean producing areas of Brazil, Bolivia, and Columbia (22). The pathogen was first reported in the continental United States in November 2004 (18). Yield losses associated with this disease range from 40 to $60 \%$, with losses up to $80 \%$ in experimental plots $(2,6)$. The presence of this disease in the United States may impact soybean (Glycine $\max$ (L.) Merr.) production, as current commercial varieties are considered to be susceptible (13), and application of fungicide will add to the cost of production.

Corresponding author: M. R. Miles

E-mail: mrmiles@express.cites.uiuc.edu

* The $\boldsymbol{e}$-Xtra logo stands for "electronic extra" and indicates that two supplementary appendices not included in the print edition are available online.

Accepted for publication 2 September 2007.

doi:10.1094/PDIS-92-1-0096

This article is in the public domain and not copyrightable. It may be freely reprinted with customary crediting of the source. The American Phytopathological Society, 2008.
Field evaluations in Taiwan and India identified soybean accessions that were resistant to $P$. pachyrhizi $(2,6)$. Four single dominant genes identified as $R p p_{1}(10,12)$, $R p p_{2}(3,10), R_{p p}(3,19)$, and $R p p_{4}$ (9) have been reported to confer resistance to P. pachyrhizi. However, each of the four genes conditions resistance to a limited set of specific $P$. pachyrhizi isolates $(1,3,7)$. There are three reaction types associated with soybean rust: the two resistant reactions, immune (I) and reddish-brown (RB), and the susceptible tan (TAN) $(2,3)$. The immune reaction, where no visible symptoms are observed, has only been reported with $R p p_{1}$ when inoculated with a few $P$. pachyrhizi isolates, including India 73-1 $(1,2)$. These single-gene sources have not been durable when used in commercial cultivars and have not been effective when challenged with additional isolates of $P$. pachyrhizi $(1,8)$.

Partial resistance to $P$. pachyrhizi, also referred to as rate reducing resistance, has been described in soybean $(4,20)$. In greenhouse inoculation studies, hostpathogen combinations that resulted in RB reactions tended to have longer latent periods, lower rates of increase in pustule number over time, and smaller lesions compared with combinations that resulted in a TAN reaction $(2,4,11)$. In field evaluations conducted in Asia and India, accessions that had fewer lesions were identified as moderately resistant compared with accessions that were identified as susceptible $(2,8,19,20)$. Identification and utilization of partial resistance in breeding programs has been limited, and more research is needed to fully utilize partial resistance traits.

The U.S. Department of AgricultureAgricultural Research Service (USDAARS) Soybean Germplasm Collection was evaluated for resistance to soybean rust by inoculating seedlings with a mixture of four $P$. pachyrhizi isolates in the USDAARS Foreign Disease-Weed Science Research Unit (FDWSRU) Biosafety Level 3 containment greenhouses (14). From more than 16,000 accessions in the collection that were evaluated, 805 were reported to have low severity ratings or the presence of an RB lesion type. These selected accessions have the potential to provide soybean rust resistance genes that may be useful for incorporation into commercial soybean cultivars, but further evaluations are needed to determine their potential as resistance sources.

The objective of this study was to evaluate the resistance in adult plants of the soybean accessions that had been previously identified in greenhouse evaluations in the United States (14) as potential sources of resistance to $P$. pachyrhizi in field trials conducted in Paraguay. The overall goal was to identify accessions with low soybean rust severities that may provide new sources of resistance genes for incorporation into commercial soybean cultivars.

\section{MATERIALS AND METHODS}

Field design. Five hundred thirty soybean accessions from maturity groups (MG) III through IX were evaluated for resistance to $P$. pachyrhizi in a field trial during the 2005-06 growing season at the Centro Regional de Investigación Agrícola (CRIA), a research station of the Ministerio de Agricultura y Ganadería, in Capitán Miranda, Itapúa, Paraguay (latitude $27^{\circ} 11^{\prime} 60^{\prime \prime} \mathrm{S}$ and longitude $55^{\circ} 47^{\prime} 60^{\prime \prime} \mathrm{W}$ ). The field design was a randomized com- 
plete block with accessions blocked by maturity group to reduce the effect of maturity on soybean rust evaluation. There were four replications within each maturity group block. Plots were single rows, $1 \mathrm{~m}$ in length and spaced $45 \mathrm{~cm}$ apart with a 1$\mathrm{m}$ alley between ranges. Plots were handplanted, 21 to 23 November 2005, with 50 seeds and thinned 2 weeks later to one plant every $5 \mathrm{~cm}$. The field was surrounded with rows of the susceptible, early maturing soybean cultivar Pua 'e, that were planted 4 weeks prior to the soybean accessions. In addition, interior border and spreader rows were planted at the same time as the accessions. The internal spreader rows were one row each of the susceptible cultivars Pua 'e and Camila 6.4 , planted after every 10 rows of accessions. These internal spreader rows were inoculated with a liquid suspension of $P$. pachyrhizi urediniospores, $0.5 \mathrm{~g} /$ liter water with $0.1 \%$ Tween 20 (vol/vol), on 7 - to 10 day intervals throughout the season. Inoculum was applied using a backpack sprayer equipped with a hand pump. The application wand was placed between the spreader rows and held at midcanopy with the application tip pointed down. Inoculations were typically done in late afternoon. Urediniospores were collected just prior to use by brushing leaves of infected soybean cultivar Pua 'e plants growing in soil beds in screenhouses at CRIA. P. pachyrhizi has been maintained in these screenhouses since the initial discovery of the pathogen in Paraguay, through sequential planting of susceptible cultivars. Overhead irrigation was applied using impact sprinklers (Senninger Series 20 209HD-1-11/2'M with \#6-Gold nozzle, Senninger of Brazil LTD, Hollambra, Sao Paulo, Brazil) spaced $10 \mathrm{~m}$ apart, two or three times during the day. As the first soybean plants in the field reached flowering, the impact sprinklers were replaced with a mini-wobbler tip that produced smaller drops (Senninger Mini Wobbler, \#6-Gold nozzle, Senninger of Brazil LTD). Irrigation was applied for 2 days with no irrigation the third day, throughout the course of the field trails. The accessions from MG III, IV, and V and the internal spreader rows were replanted on 6 April 2006 using the same field design and protocols described above, and the plots were evaluated in June and July 2006.

Soybean rust assessment. Soybean rust was evaluated on a row basis by selecting five of the larger trifoliolates within the middle third of the canopy within each plot. The severity assessment was adapted from one previously published (15) using a 1 to 9 scale, where a rating of 1 was no soybean rust present on any leaflet (resistant), and a rating of 9 was greater than $20 \%$ of the leaflet surface infected by rust (susceptible) (Table 1). The presence of $\mathrm{RB}$ lesions or a mixture of $\mathrm{RB}$ and TAN lesions (MX) was recorded, as well as the sporulation level within the RB lesions. When no lesions were observed in midcanopy, additional trifoliolates from the lower canopy were examined to determine lesion type and confirm the absence of soybean rust within the plot. Sporulation within RB lesions was rated on a 1 to 5 scale: $1=$ no sporulation, 2 = sporulation less then $25 \%$ of a fully sporulating lesion, $3=50 \%$ sporulation of a fully sporulating TAN lesion, $4=$ sporulation $75 \%$ of a fully sporulating TAN lesion, and $5=$ sporulation comparable to a fully sporulating TAN lesion. Where there were differences among the five trifoliolates in the sample, the most severely infected trifoliolates

Table 1. Severity assessment scale used to evaluate soybean accessions for resistance to soybean rust in field trials at Centro Regional de Investigación Agrícola, Capitan Miranda, Itapúa, Paraguay

\begin{tabular}{cccc}
\hline $\begin{array}{c}\text { Soybean rust } \\
\text { severity rating }\end{array}$ & \multicolumn{2}{c}{$\begin{array}{c}\text { Percentage of leaflet surface } \\
\text { covered with soybean rust lesions }\end{array}$} & $\begin{array}{c}\text { Number of soybean } \\
\text { Nover }\end{array}$ \\
\cline { 2 - 3 } rust lesions per leaflet $^{\mathbf{b}}$
\end{tabular}

a The midpoint was used for all statistical analysis.

$\mathrm{b}$ The number of lesions per leaflet was obtained from scanned templates used to develop the severity rating scale (15); actual lesions per leaflet were not counted in the field.
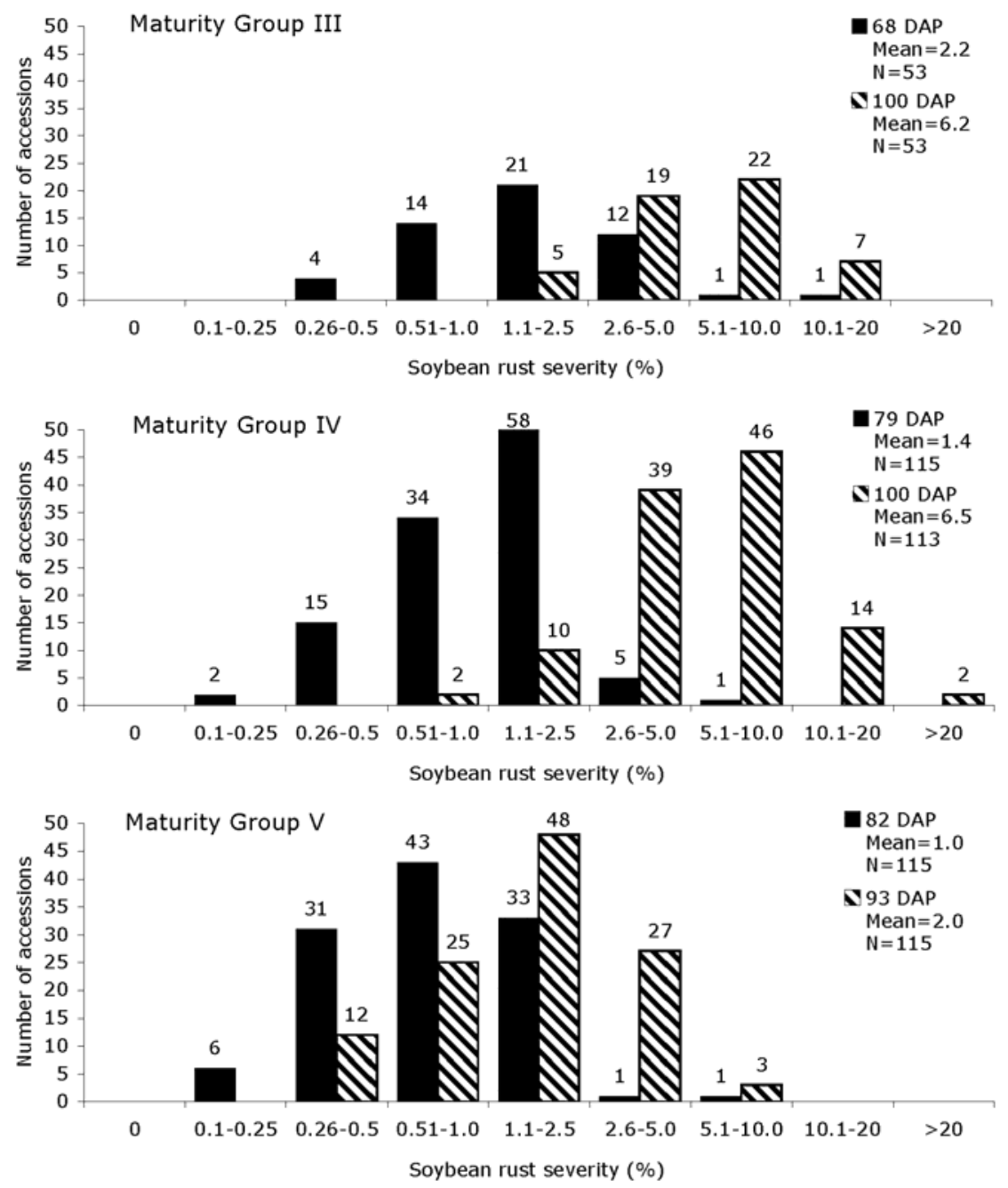

Fig. 1. Distribution of mean soybean rust severities for the accessions in maturity groups III, IV, and V evaluated in June and July 2006 from a field trial conducted at Centro Regional de Investigación Agrícola, Capitán Miranda, Itapúa, Paraguay. Maturity groups were evaluated at different days after planting (DAP), and were of different sizes (N). 
Table 2. Soybean accessions from maturity groups III, IV, and V with the lowest percentage soybean rust severity in June and July 2006 or with reddishbrown (RB) lesions in three of four replications from field evaluations of adult plants conducted at Centro Regional de Investigación Agrícola, Capitán Miranda, Itapúa, Paraguay

\begin{tabular}{|c|c|c|c|c|c|c|c|c|}
\hline Accession & $\begin{array}{c}\text { No. } \\
\text { of reps }\end{array}$ & $\begin{array}{c}\text { Mean SBR } \\
\text { severity } \\
(\%)^{\mathrm{a}}\end{array}$ & $\mathbf{C I} \pm^{\mathbf{b}}$ & $\begin{array}{c}\text { No. } \\
\text { of reps }\end{array}$ & $\begin{array}{c}\text { Mean SBR } \\
\text { severity } \\
(\%)^{\mathrm{a}}\end{array}$ & $\mathbf{C I} \pm^{\mathbf{b}}$ & $\begin{array}{c}\text { No. of reps } \\
\text { with RB } \\
\text { lesions }\end{array}$ & $\begin{array}{c}\text { Sporulation } \\
\text { within RB } \\
\text { lesions }^{\mathbf{e}}\end{array}$ \\
\hline Maturity group III & \multicolumn{3}{|c|}{ Evaluation at 68 DAP } & \multicolumn{3}{|c|}{ Evaluation at 100 DAP } & & \\
\hline PI 567351B & 3 & 0.5 & 2.2 & 3 & 1.1 & 4.4 & 1 & 5 \\
\hline PI 612759D & 4 & 1.8 & 1.9 & 4 & 1.8 & 3.7 & - & - \\
\hline PI 507473 & 4 & 0.9 & 1.9 & 2 & 2.0 & 4.7 & - & - \\
\hline PI 068806 & 3 & 0.8 & 2.2 & 4 & 2.2 & 3.7 & - & - \\
\hline PI 437684 & 4 & 0.4 & 1.9 & 3 & 2.5 & 4.4 & - & - \\
\hline PI 612750 & 3 & 0.7 & 2.2 & 3 & 2.7 & 4.4 & - & - \\
\hline PI 464920B & 4 & 0.7 & 1.9 & 4 & 3.0 & 3.7 & 1 & 5 \\
\hline PI 567457 & 4 & 0.9 & 1.9 & 4 & 3.0 & 3.7 & - & - \\
\hline PI 479735 & 4 & 1.3 & 1.9 & 4 & 3.0 & 3.7 & - & - \\
\hline PI 599509 & 3 & 0.8 & 2.2 & 3 & 3.3 & 4.4 & - & - \\
\hline PI 068494 & 3 & 1.1 & 2.2 & 4 & 3.3 & 3.7 & - & - \\
\hline PI $437500 B$ & 4 & 0.5 & 1.9 & 4 & 3.8 & 3.7 & - & - \\
\hline PI 561330A & 4 & 0.8 & 1.9 & 4 & 3.8 & 3.7 & - & - \\
\hline PI 567418C & 3 & 1.7 & 2.2 & 1 & 3.8 & - & 2 & 5 \\
\hline PI 229333 & 4 & 2.0 & 1.9 & 1 & 3.8 & - & 1 & 5 \\
\hline PI 567365 & 3 & 2.4 & 2.2 & 4 & 3.8 & 3.7 & - & - \\
\hline PI 507279 & 3 & 2.5 & 2.2 & 3 & 3.8 & 4.4 & - & - \\
\hline PI 603392 & 4 & 2.6 & 1.9 & 3 & 3.8 & 4.4 & 2 & 5 \\
\hline PI 423730B & 3 & 6.8 & 2.2 & 1 & 3.8 & - & 1 & 5 \\
\hline PI 567404A & 3 & 1.6 & 2.2 & 4 & 4.1 & 3.7 & 3 & 5 \\
\hline PI 091730 & 3 & 1.9 & 2.2 & 2 & 4.6 & 4.7 & & \\
\hline PI 567487 & 4 & 0.5 & 1.9 & 3 & 4.9 & 4.4 & - & - \\
\hline PI 552538 & 3 & 0.7 & 2.2 & 3 & 4.9 & 4.4 & 1 & 5 \\
\hline PI 547878 & 4 & 2.7 & 1.9 & 3 & 4.9 & 4.4 & - & - \\
\hline PI 538377 & 4 & 2.5 & 1.9 & 3 & 5.1 & 4.4 & - & - \\
\hline MG III mean & \multicolumn{3}{|c|}{2.2} & \multicolumn{3}{|c|}{6.2} & & \\
\hline Number of accessions & \multicolumn{3}{|c|}{53} & \multicolumn{3}{|c|}{$53^{c}$} & & \\
\hline Maturity group IV & \multicolumn{3}{|c|}{ Evaluation at 79 DAP } & \multicolumn{3}{|c|}{ Evaluation at 100 DAP } & & \\
\hline PI 506863 & 4 & 0.4 & 1.0 & 1 & 0.8 & - & 1 & 5 \\
\hline PI 567341 & 4 & 0.8 & 1.0 & 1 & 0.8 & - & - & - \\
\hline PI 567409A & 4 & 0.2 & 1.0 & 1 & 1.8 & - & - & - \\
\hline PI 567522A & 4 & 0.4 & 1.0 & 2 & 1.8 & 2.9 & - & - \\
\hline PI 603490 & 4 & 1.6 & 1.0 & 2 & 1.8 & 2.9 & - & - \\
\hline PI 424299A & 4 & 0.4 & 1.0 & 2 & 2.0 & 2.9 & 3 & 5 \\
\hline PI 506847 & 4 & 0.4 & 1.0 & 2 & 2.0 & 2.9 & - & - \\
\hline PI 424386B & 4 & 0.6 & 1.0 & 2 & 2.0 & 2.9 & - & - \\
\hline PI 567556 & 3 & 0.7 & 1.2 & 2 & 2.0 & 2.9 & - & - \\
\hline PI 507021 & 4 & 1.5 & 1.0 & 2 & 2.0 & 2.9 & - & - \\
\hline PI 567679C & 4 & 2.5 & 1.0 & 2 & 2.0 & 2.9 & 1 & 5 \\
\hline PI 423766 & 4 & 0.8 & 1.0 & 2 & 2.8 & 2.9 & - & - \\
\hline PI 424294B & 4 & 3.6 & 1.0 & 3 & 3.1 & 2.6 & - & - \\
\hline PI 567491B & 4 & 0.9 & 1.0 & 2 & 3.3 & 2.9 & - & - \\
\hline PI 408133 & 4 & 1.1 & 1.0 & 4 & 3.3 & 2.3 & 3 & 5 \\
\hline PI 398359 & 4 & 0.5 & 1.0 & 4 & 4.1 & 2.3 & 3 & 5 \\
\hline PI 408203A & 3 & 0.8 & 1.2 & 3 & 4.9 & 2.6 & 3 & 5 \\
\hline PI 606434 & 4 & 1.8 & 1.0 & 4 & 8.0 & 2.3 & 3 & 4 \\
\hline MG IV mean & & 1.4 & & & 6.5 & & & \\
\hline \multirow[t]{2}{*}{ Number of accessions } & & 115 & & & $110^{\mathrm{c}}$ & & & \\
\hline & & & & & & & \multicolumn{2}{|c|}{ (continued on next page) } \\
\hline
\end{tabular}

a Soybean rust (SBR) severity was evaluated visually in midcanopy using a 1 to 9 scale with: $1=$ no soybean rust present, $2=$ up to $0.25 \%$ of surface affected, $3=$ up to $0.5 \%$ of surface affected, $4=$ up to $1 \%$ of leaflet surface affected, $5=$ up to $2.5 \%$ of surface affected, $6=$ up to $5 \%$ of surface affected, $7=$ up to $10 \%$ of leaflet affected, $8=$ up to $20 \%$ of leaflet surface affected, and $9=$ over $20 \%$ of leaflet surface affected. Values were converted to midpoint of percentage range for each rating prior to analysis then transformed, $\log _{10}(1+X)$. Means and CI were back transformed for clarity.

${ }^{\mathrm{b}} \mathrm{CI}$ is $95 \%$ confidence interval, $P=0.05$. - was used to indicate a lack of a confidence interval for accessions with data from a single replication.

c The difference in the number of accessions and number of replications for each accession evaluated on each assessment date was due to accessions that defoliated prior to the second assessment.

${ }^{\mathrm{d}}$ Presence of RB lesion type was determined visually, and the row was considered positive if the RB lesion type was observed on one or both assessment dates. - was used to indicate no RB lesions observed in any replications.

e Sporulation within the RB lesion was evaluated visually on a 1 to 5 scale: $1=$ no sporulation, $2=$ sporulation less than $25 \%$ of a susceptible tan (TAN) lesion, $3=50 \%$ sporulation of a TAN lesion, $4=$ sporulation was $75 \%$ of a TAN lesion, and $5=$ sporulation comparable to a fully sporulating lesion. - was used to indicate no sporulation levels were assessed as no RB lesions were observed.

were used to determine the rating for both severity and sporulation.

Days after planting (DAP) to harvest maturity were recorded for each plot in the November 2005 planting. The growth stage (5) of each plot was recorded prior to the first assessment date for MG VI, VII, VIII, and IX. The growth stage of each plot in MG III, $\mathrm{IV}$, and $\mathrm{V}$ were recorded prior to both assessment dates in the April 2006 planting.
Greenhouse and field evaluation of resistant accessions. A total of 10 accessions from MG VI, VII, VIII, and IX with severities less than $0.2 \%$ on the first assessment date in the November 2005 plant- 
Table 2. (continued from preceding page)

\begin{tabular}{|c|c|c|c|c|c|c|c|c|}
\hline Accession & $\begin{array}{c}\text { No. } \\
\text { of reps }\end{array}$ & $\begin{array}{c}\text { Mean SBR } \\
\text { severity } \\
(\%)^{\mathrm{a}}\end{array}$ & $\mathbf{C I} \pm^{\mathbf{b}}$ & $\begin{array}{c}\text { No. } \\
\text { of reps }\end{array}$ & $\begin{array}{c}\text { Mean SBR } \\
\text { severity } \\
(\%)^{\mathbf{a}}\end{array}$ & $\mathbf{C I} \pm^{\mathbf{b}}$ & $\begin{array}{c}\text { No. of reps } \\
\text { with RB } \\
\text { lesions }^{d}\end{array}$ & $\begin{array}{c}\text { Sporulation } \\
\text { within RB } \\
\text { lesions }^{\mathbf{e}}\end{array}$ \\
\hline Maturity group V & \multicolumn{3}{|c|}{ Evaluation at 82 DAP } & \multicolumn{3}{|c|}{ Evaluation at 93 DAP } & & \\
\hline PI 181546 & 4 & 0.2 & 0.9 & 3 & 0.3 & 1.7 & - & - \\
\hline PI 398288 & 4 & 0.2 & 0.9 & 3 & 0.3 & 1.7 & - & - \\
\hline PI 408134B & 4 & 0.2 & 0.9 & 3 & 0.3 & 1.7 & - & - \\
\hline PI 507305 & 3 & 0.2 & 0.9 & 3 & 0.3 & 1.7 & 1 & 0 \\
\hline PI 567390 & 4 & 0.2 & 0.9 & 4 & 0.4 & 1.5 & - & - \\
\hline PI 407831 & 4 & 0.3 & 0.9 & 4 & 0.4 & 1.5 & - & - \\
\hline PI 567376A & 4 & 0.3 & 0.9 & 4 & 0.4 & 1.5 & - & - \\
\hline PI 507566 & 4 & 0.6 & 0.9 & 3 & 0.4 & 1.7 & 2 & 1.5 \\
\hline PI 594784A & 3 & 0.3 & 0.9 & 3 & 0.5 & 1.7 & - & - \\
\hline PI 567382B & 4 & 0.4 & 0.9 & 3 & 0.5 & 1.7 & - & - \\
\hline PI 407822 & 4 & 0.4 & 0.9 & 4 & 0.5 & 1.5 & 1 & 4 \\
\hline PI 408059 & 4 & 0.4 & 0.9 & 4 & 0.5 & 1.5 & - & - \\
\hline PI 458273 & 4 & 0.2 & 0.9 & 3 & 0.6 & 1.7 & - & - \\
\hline PI 398377 & 4 & 0.3 & 0.9 & 4 & 0.6 & 1.5 & 1 & 5 \\
\hline PI 603584 & 4 & 0.3 & 0.9 & 4 & 0.6 & 1.5 & - & - \\
\hline PI 549019 & 4 & 0.4 & 0.9 & 4 & 0.6 & 1.5 & - & - \\
\hline PI 567230 & 4 & 0.4 & 0.9 & 4 & 0.6 & 1.5 & - & - \\
\hline PI 407846 & 4 & 1.2 & 0.9 & 3 & 0.6 & 1.7 & - & - \\
\hline PI 587598A & 4 & 0.3 & 0.9 & 4 & 0.7 & 1.5 & - & - \\
\hline PI 086078 & 4 & 0.4 & 0.9 & 4 & 0.7 & 1.5 & - & - \\
\hline PI 407819 & 4 & 0.4 & 0.9 & 4 & 0.7 & 1.5 & - & - \\
\hline PI 567206 & 4 & 0.4 & 0.9 & 4 & 0.7 & 1.5 & - & - \\
\hline PI 423823 & 3 & 0.5 & 1.0 & 3 & 0.7 & 1.7 & - & - \\
\hline PI 417445 & 4 & 0.5 & 0.9 & 4 & 0.7 & 1.5 & 1 & 4 \\
\hline PI 507518 & 4 & 0.5 & 0.9 & 4 & 0.7 & 1.5 & - & - \\
\hline PI 606408 & 4 & 0.6 & 0.9 & 4 & 0.7 & 1.5 & 2 & 2.5 \\
\hline PI 407882 & 4 & 2.2 & 0.9 & 3 & 0.7 & 1.7 & - & - \\
\hline PI 408122 & 4 & 0.4 & 0.9 & 4 & 0.8 & 1.5 & - & - \\
\hline PI 416851 & 4 & 0.4 & 0.9 & 4 & 0.8 & 1.5 & - & - \\
\hline PI 407859-1 & 3 & 0.5 & 1.0 & 3 & 0.8 & 1.7 & - & - \\
\hline PI 423722 & 3 & 0.8 & 1.0 & 2 & 0.8 & 2.1 & - & - \\
\hline PI 594013 & 4 & 0.3 & 0.9 & 4 & 0.9 & 1.5 & - & - \\
\hline PI 417105 & 4 & 0.4 & 0.9 & 3 & 0.9 & 1.7 & - & - \\
\hline PI 567388 & 4 & 0.5 & 0.9 & 4 & 0.9 & 1.5 & 2 & 4 \\
\hline PI 567397 & 3 & 0.7 & 1.0 & 3 & 0.9 & 1.7 & - & - \\
\hline PI 355069S & 3 & 0.8 & 1.0 & 3 & 0.9 & 1.7 & - & - \\
\hline PI 408088 & 4 & 0.7 & 0.9 & 4 & 1.0 & 1.5 & - & - \\
\hline PI 274508 & 4 & 0.7 & 0.9 & 4 & 3.3 & 1.5 & 3 & 2 \\
\hline MG V mean & & 1.0 & & & 2.0 & & & \\
\hline Number of accessions & & 115 & & & 115 & & & \\
\hline
\end{tabular}

ing were evaluated in the greenhouse at CRIA during June and July 2006. Six seeds of each accession were planted in 4liter pots using local soil containing 5\% rice hulls ( $\mathrm{vol} / \mathrm{vol})$ and placed in a greenhouse at 20 to $28^{\circ} \mathrm{C}$ under natural light for 3 weeks. Soybean rust was collected from the border plants of the field experiment and increased on the cultivar Pua ' $e$ in the greenhouse. Inoculum for the experiment was prepared from fresh spores collected from those plants; urediniospores were diluted to 20,000 per $\mathrm{ml}$ in distilled water with $0.1 \%$ Tween 20 (vol/vol) and inoculated to runoff several times using a 500ml-capacity paint gun attached to an air compressor set at $138 \mathrm{kPa}$. Inoculated plants were placed in a dew chamber at 20 to $25^{\circ} \mathrm{C}$ overnight. The severity of soybean rust infection, the presence of $\mathrm{RB}$ or TAN lesions, and the sporulation level within uredinia were recorded from the first trifoliate on each plant. The susceptible cultivars Pua 'e and Camila 6.4 were included as susceptible controls.

The 10 accessions were planted 1 November 2006, 10 December 2006, and 10
January 2007 in the field under irrigation at CRIA, using a randomized complete block design with four, two, and two replications for each planting date, respectively. The accessions were planted in 1-m rows, 10 to 15 seeds per plot, in blocks 10 rows wide that were bordered by the susceptible cultivars Pua 'e and Camila 6.4. All other field procedures were as described above. Due to limited seed, the accessions PI 567145C, PI 594754, and PI 594760B were not included in the second and third planting dates. Soybean rust severity, the presence of $\mathrm{RB}$ or TAN lesions, and the sporulation level within uredinia were evaluated as described above. When no lesions were observed in midcanopy, trifoliolates from the lower canopy were examined to determine lesion type. Accessions from MG III, IV, and V were not included in the 2006-07 greenhouse and field experiments, because after replanting there was insufficient seed with acceptable germination for further testing.

Statistical analysis. All statistical analysis was performed using JMP® version 5.01 statistical software (SAS Insti- tute, Cary, NC). Severity data from the field trials were converted from the 1 to 9 severity ratings into percentages using the midpoint of the range for each rating (Table 1). The percentages were then transformed using $\log _{10}(1+X)$, where $X$ was the percent severity ranging from 0.000 to 0.300 . Since the numbers of replications for each accession in the field trials were not equal, means were compared using confidence intervals. Students' LSD was used to compare means of the 10 accessions in the 2006 field experiments. Unless otherwise stated, all differences were significant at $P \leq 0.05$. No statistical analysis was done in the nonreplicated greenhouse experiment or with the level of sporulation within RB lesion data. Accession means and confidence intervals were back transformed to percentages for clarity.

\section{RESULTS}

Field evaluation. Soybean rust was present at low levels in the lower canopy of the border and spreader rows in midFebruary 2006. Rust severity increased in the border and spreader rows and was ob- 
Table 3. Soybean accessions from maturity groups VI, VII, VIII, and IX with the lowest percentage soybean rust severity in March 2006 or with reddishbrown (RB) lesions in three of four replications from field evaluations of adult plants conducted at Centro Regional de Investigación Agrícola, Capitán Miranda, Itapúa, Paraguay

\begin{tabular}{|c|c|c|c|c|c|c|c|c|}
\hline Accession & $\begin{array}{c}\text { No. } \\
\text { of reps }\end{array}$ & $\begin{array}{c}\text { Mean SBR } \\
\text { severity } \\
(\%)^{\mathbf{a}}\end{array}$ & $\mathrm{CI} \pm^{\mathrm{b}}$ & $\begin{array}{c}\text { No. } \\
\text { of reps }\end{array}$ & $\begin{array}{c}\text { Mean SBR } \\
\text { severity } \\
(\%)^{\mathrm{a}}\end{array}$ & $\mathbf{C I} \pm^{\mathbf{b}}$ & $\begin{array}{c}\text { No. of reps } \\
\text { with RB } \\
\text { lesions }^{d}\end{array}$ & $\begin{array}{c}\text { Sporulation } \\
\text { within RB } \\
\text { lesions }^{\mathbf{e}}\end{array}$ \\
\hline Maturity group VI & \multicolumn{3}{|c|}{ Evaluation at 106 DAP } & & & & & \\
\hline PI 587886 & 4 & 0.0 & 4.4 & - & - & - & - & - \\
\hline PI 587880A & 4 & 0.2 & 4.4 & - & - & - & - & - \\
\hline PI 587880B & 4 & 0.2 & 4.4 & - & - & - & - & - \\
\hline PI 605781E & 4 & 0.5 & 5.3 & - & - & - & - & - \\
\hline PI 379620 & 4 & 0.7 & 4.4 & - & - & - & - & - \\
\hline PI 615437 & 4 & 0.8 & 4.4 & - & - & - & - & - \\
\hline PI 594740A & 4 & 0.9 & 4.4 & - & - & - & 1 & 1.0 \\
\hline PI 605781A & 4 & 1.1 & 4.4 & - & - & - & - & - \\
\hline PI 567189A & 4 & 1.2 & 4.4 & - & - & - & - & - \\
\hline PI 578319A & 4 & 1.3 & 4.4 & - & - & - & - & - \\
\hline PI 506939 & 4 & 1.4 & 4.4 & - & - & - & - & - \\
\hline PI 438426 & 4 & 1.5 & 4.4 & - & - & - & - & - \\
\hline PI 417503 & 4 & 1.7 & 4.4 & - & - & - & - & - \\
\hline PI 605773 & 4 & 1.9 & 4.4 & - & - & - & - & - \\
\hline PI 566992A & 2 & 2.0 & 6.8 & - & - & - & - & - \\
\hline PI 587687A & 4 & 2.0 & 4.4 & - & - & - & - & - \\
\hline PI 548463 & 3 & 2.5 & 5.3 & - & - & - & - & - \\
\hline PI 340050 & 4 & 2.8 & 4.4 & - & - & - & - & - \\
\hline PI 605791A & 4 & 3.2 & 4.4 & - & - & - & - & - \\
\hline PI 408085 & 4 & 3.5 & 4.4 & - & - & - & - & - \\
\hline PI 423852 & 4 & 3.6 & 4.4 & - & - & - & - & - \\
\hline PI 605857A & 4 & 3.6 & 4.4 & - & - & - & - & - \\
\hline PI 578326 & 3 & 3.8 & 5.3 & - & - & - & 1 & 5.0 \\
\hline PI 578323B & 4 & 3.9 & 4.4 & - & - & - & - & - \\
\hline PI 594758A & 4 & 3.9 & 4.4 & - & - & - & - & - \\
\hline PI 578323A & 4 & 4.0 & 4.4 & - & - & - & - & - \\
\hline PI 605789A & 4 & 4.1 & 4.4 & - & - & - & - & - \\
\hline MG VI mean & \multirow{2}{*}{\multicolumn{3}{|c|}{$\begin{array}{c}6.7 \\
55\end{array}$}} & & & & & \\
\hline Number of accessions & & & & & & & & \\
\hline Maturity group VII & \multicolumn{3}{|c|}{ Evaluation at 106 DAP } & \multicolumn{3}{|c|}{ Evaluation at 129 DAP } & & \\
\hline PI 587905 & 4 & 0.1 & 3.4 & 4 & 0.5 & 4.1 & 3 & 0.7 \\
\hline PI 566989A & 4 & 2.5 & 3.4 & 1 & 1.8 & - & - & - \\
\hline PI 594172A & 4 & 4.6 & 3.4 & 4 & 1.8 & 9.8 & - & - \\
\hline PI 507002 & 3 & 4.7 & 4.1 & 2 & 1.8 & 9.8 & - & - \\
\hline PI 200492 (Rppl) & 4 & 5.1 & 3.4 & 2 & 2.2 & 9.8 & - & - \\
\hline PI 417115 & 4 & 0.2 & 3.4 & 3 & 2.7 & 4.9 & 1 & 2.0 \\
\hline PI 578306B & 4 & 0.4 & 3.4 & 1 & 3.8 & - & - & - \\
\hline PI $230970\left(R p p_{2}\right)$ & 4 & 0.4 & 3.4 & 4 & 3.8 & 4.1 & 4 & 2.5 \\
\hline PI 587767B & 4 & 2.0 & 3.4 & 1 & 3.8 & - & - & - \\
\hline PI 423923 & 4 & 1.9 & 3.4 & 3 & 12.8 & 4.9 & 3 & 2.7 \\
\hline PI 507259 & 4 & 0.3 & 3.4 & 3 & 13.1 & 4.9 & 3 & 2.3 \\
\hline MG VII mean & & 3.7 & & & 10.9 & & & \\
\hline \multirow[t]{2}{*}{ Number of accessions } & & 43 & & & $27^{c}$ & & & \\
\hline & & & & & & & \multicolumn{2}{|c|}{ (continued on next page) } \\
\hline
\end{tabular}

a Soybean rust (SBR) severity was evaluated visually in midcanopy using a 1 to 9 scale with: $1=$ no soybean rust present, $2=$ up to $0.25 \%$ of surface affected, $3=$ up to $0.5 \%$ of surface affected, $4=$ up to $1 \%$ of leaflet surface affected, $5=$ up to $2.5 \%$ of surface affected, $6=$ up to $5 \%$ of surface affected, $7=$ up to $10 \%$ of leaflet affected, $8=$ up to $20 \%$ of leaflet surface affected, and $9=$ over $20 \%$ of leaflet surface affected. Values were converted to midpoint of percentage range for each rating prior to analysis then transformed, $\log _{10}(1+X)$. Means and CI were back transformed for clarity.

${ }^{\mathrm{b}} \mathrm{CI}$ is $95 \%$ confidence interval, $P=0.05$. - was used to indicate a lack of a confidence interval for accessions with data from a single replication.

${ }^{c}$ The difference in the number of accessions and number of replications for each accession evaluated on each assessment date was due to accessions that defoliated prior to the second assessment.

${ }^{\mathrm{d}}$ Presence of RB lesion type was determined visually, and the row was considered positive if the RB lesion type was observed on one or both assessment dates. - was used to indicate no RB lesions observed in any replications.

e Sporulation within the RB lesion was evaluated visually on a 1 to 5 scale: $1=$ no sporulation, $2=$ sporulation less than $25 \%$ of a TAN lesion, $3=50 \%$ sporulation of a TAN lesion, $4=$ sporulation was $75 \%$ of a TAN lesion, and $5=$ sporulation comparable to a fully sporulating TAN lesion. - was used to indicate no sporulation levels were assessed as no RB lesions were observed.

served in the rows of the accessions during the first week of March. The 281 soybean accessions in MG III, IV, and V had started to senesce by 7 March, before the soybean rust epidemic started, so no soybean rust evaluation was done for this planting. However, the DAP to harvest maturity was recorded, and seed was harvested from each row, replanted in April, and evaluated in June and July. Accessions in MG VI,
VII, VII, and IX were evaluated 7 to 13 March, with a second evaluation on 30 and 31 March. Frequent rain interfered with evaluation from 20 March through 29 March. MG VI accessions were not evaluated in late March as the plants were mature and most had defoliated. Only a subset of the accessions in MG VII retained enough leaf material for evaluation on 30 to 31 March. Within each MG, the growth stage and days to harvest maturity of the accessions tended to be similar.

MG III, IV, and V. Across the 281 accessions in MG III, IV, and V, the percentage soybean rust severity ranged from 0.2 to $30.0 \%$ when evaluated in the second planting (Fig. 1). Soybean rust severity of individual trifoliolates from the midcanopy of the spreader rows ranged from 7.5 to $30.0 \%$ on both assessment dates. Soybean 
Table 3. (continued from preceding page)

\begin{tabular}{|c|c|c|c|c|c|c|c|c|}
\hline Accession & $\begin{array}{c}\text { No. } \\
\text { of reps }\end{array}$ & $\begin{array}{c}\text { Mean SBR } \\
\text { severity } \\
(\%)^{\mathrm{a}}\end{array}$ & $\mathrm{CI} \pm^{\mathrm{b}}$ & $\begin{array}{c}\text { No. } \\
\text { of reps }\end{array}$ & $\begin{array}{c}\text { Mean SBR } \\
\text { severity } \\
(\%)^{\mathrm{a}}\end{array}$ & $\mathbf{C I} \pm^{\mathbf{b}}$ & $\begin{array}{c}\text { No. of reps } \\
\text { with } R B \\
\text { lesions }^{d}\end{array}$ & $\begin{array}{c}\text { Sporulation } \\
\text { within RB } \\
\text { lesions }^{\mathrm{e}}\end{array}$ \\
\hline Maturity group VIII & \multicolumn{3}{|c|}{ Evaluation at 108 DAP } & \multicolumn{3}{|c|}{ Evaluation at 129 DAP } & & \\
\hline PI 605779E & 4 & 1.1 & 3.0 & 3 & 0.9 & 4.7 & - & - \\
\hline PI 567024 & 2 & 1.3 & 4.0 & 1 & 3.8 & - & - & - \\
\hline PI 594510C & 4 & 0.9 & 3.0 & 4 & 3.9 & 3.9 & - & - \\
\hline PI 459025B $\left(R p p_{4}\right)$ & 4 & 1.8 & 3.0 & 4 & 4.1 & 3.9 & - & - \\
\hline PI 417120 & 4 & 7.3 & 3.0 & 2 & 4.4 & 6.0 & - & - \\
\hline PI 594756 & 4 & 0.3 & 3.0 & 4 & 4.5 & 3.9 & 1 & 1.5 \\
\hline PI 594510B & 4 & 2.0 & 3.0 & 4 & 4.6 & 3.9 & - & - \\
\hline PI 506947 & 4 & 1.3 & 3.0 & 4 & 5.4 & 3.9 & - & - \\
\hline PI 417117 & 3 & 2.0 & 3.0 & 2 & 5.5 & 6.0 & - & - \\
\hline PI 605787C & 4 & 1.5 & 3.0 & 4 & 5.7 & 3.9 & 2 & 3.5 \\
\hline PI 605772 & 4 & 2.3 & 3.0 & 4 & 6.0 & 3.9 & 3 & 3.3 \\
\hline PI 416778 & 4 & 2.5 & 3.0 & 4 & 9.7 & 3.9 & 3 & 3.7 \\
\hline PI 416819A & 4 & 1.5 & 3.0 & 4 & 18.9 & 3.9 & 3 & 2.3 \\
\hline MG VIII mean & \multicolumn{3}{|c|}{4.8} & \multicolumn{3}{|c|}{13.9} & & \\
\hline Number of accessions & \multicolumn{3}{|c|}{78} & \multicolumn{3}{|c|}{76} & & \\
\hline Maturity group IX & \multicolumn{3}{|c|}{ Evaluation at 112 DAP } & \multicolumn{3}{|c|}{ Evaluation at 130 DAP } & & \\
\hline PI 594754 & 4 & 0.0 & 2.9 & 3 & 0.0 & 4.4 & - & - \\
\hline PI 605833 & 4 & 0.0 & 2.9 & 4 & 0.1 & 3.7 & - & - \\
\hline PI 567104B & 4 & 0.0 & 2.9 & 4 & 0.7 & 3.7 & 2 & 1.0 \\
\hline PI 567102B & 3 & 0.0 & 3.4 & 3 & 0.9 & 4.4 & 2 & 1.0 \\
\hline PI 594767B & 4 & 0.2 & 2.9 & 4 & 1.2 & 3.7 & 2 & 1.5 \\
\hline PI 567099A & 4 & 0.0 & 2.9 & 3 & 1.8 & 4.4 & 2 & 1.0 \\
\hline PI 594767A & 4 & 0.0 & 2.9 & 3 & 2.4 & 4.4 & 2 & 1.0 \\
\hline PI 566964A & 4 & 0.0 & 2.9 & 4 & 2.5 & 3.7 & - & - \\
\hline PI 594760B & 4 & 0.0 & 2.9 & 3 & 2.6 & 4.4 & 3 & 1.0 \\
\hline PI 567131B & 4 & 3.4 & 2.9 & 2 & 2.8 & 5.6 & 2 & 1.0 \\
\hline PI 605823 & 4 & 1.8 & 2.9 & 4 & 7.0 & 3.7 & 3 & 1.3 \\
\hline PI 567145C & 4 & 0.0 & 2.9 & 3 & 9.3 & 4.4 & - & - \\
\hline PI 423972 & 4 & 0.7 & 2.9 & 4 & 9.7 & 3.7 & 3 & 1.0 \\
\hline PI 594733 & 4 & 1.3 & 2.9 & 4 & 15.7 & 3.7 & 3 & 3.0 \\
\hline MG IX mean & \multicolumn{3}{|c|}{4.6} & \multicolumn{3}{|c|}{16.9} & & \\
\hline Number of accessions & \multicolumn{3}{|c|}{72} & \multicolumn{3}{|c|}{72} & & \\
\hline
\end{tabular}

rust was more severe on the second evaluation date, and the distribution within each MG shifted toward higher severity.

The mean percentage severity of the 53 accessions in MG III was 2.2 and $6.2 \%$ at 68 and 100 DAP, respectively (Fig. 1). The lowest percentage severity was observed with PI 567351B, 0.5 and $1.1 \%$ at 68 and 100 DAP, respectively, while a severity of $1.8 \%$ was observed with PI $612759 \mathrm{D}$ on both dates (Table 2). Severities less than $1.8 \%$ at 68 DAP and severity less than $3.8 \%$ at 100 DAP were observed with PI 507473, PI 068806, PI 437684, PI 612750, PI 464920B, PI 567457, PI 479735, PI 599509, PI 0684494, PI 437500B, PI 561330A, and PI 567418C. There were 11 additional accessions where the severity was less than $5.1 \%$ that were similar to PI 567351B. RB lesions were observed in three replications of PI 567404A, and in at least one replication of 15 other accessions, all with sporulation levels of 4.0 to 5.0. PI 567351B was among the accessions with the lowest percentage severity.

The mean percentage severity of the 113 accessions in MG IV was 1.4 and $6.5 \%$ at 79 and 100 DAP, respectively (Fig. 2). The lowest percentage severity was observed with PI 506863 and PI 567341, with severity $0.8 \%$, followed by PI 567409A, PI 567522A, and PI 603490, all with $1.8 \%$ severity (Table 2). Ten additional acces- sions with severities less than $3.3 \%$ were similar to PI 506863 and PI 567341. RB lesions were observed on three replications of PI 398359, PI 408133, PI 408203A, PI 424299A, PI 508296H, PI 606434, and PI $606440 \mathrm{~A}$, as well as in at least one replication of 17 additional accessions, all with sporulation levels of 4.0 to 5.0. PI 424299A was the only accession on which RB lesions were observed in at least three replications that was also among the accessions with the lowest severity. Since the data set was not complete, no statistical analysis was done on sporulation levels.

The mean percentage severity of the 115 accessions in MG V was 1.0 and $2.0 \%$ at 82 and 93 DAP, respectively (Fig. 2). The lowest percentage severity was observed with PI 181546, PI 398288, PI 408134B, and PI 507305 where a severity of $0.3 \%$ was observed at 100 DAP. There were 33 accessions with severities of $1.0 \%$ or less (Table 2) and 35 accessions with mean percentages of 1.1 to $2.0 \%$ (data not presented) that were similar to the accessions with the lowest percentage severity when evaluated at 93 DAP. A severity of $8.0 \%$ was the highest percentage severity observed on any accession in MG V. RB lesions were observed on three replications of PI 274508, with a mean sporulation level of 3.0. PI 274508 was not among the most resistant accessions, but 16 of the 28 of the accessions with RB lesions in one or two replications were among those with severities less than $2.0 \%$. Among the accessions where RB lesions were observed in one or two replications, sporulation levels of 1.0 to 2.0 were observed with PI 476905A, PI 507305, and PI 507566, while sporulation levels of 2.5 to 3.0 were observed with PI 423984, PI 518759, PI 603570D, and PI 606408. Sporulation levels of 4.0 to 5.0 were observed with the remaining accessions.

MG VI, VII, VIII, and IX. Soybean rust severity ranged from 0 through $30.0 \%$ among the 249 accessions in MG VI, VII, VIII, and IX (Fig. 2). The soybean rust severity of individual trifoliolates from the midcanopy of the spreader rows ranged from 7.5 to $30.0 \%$. Soybean rust was more severe on the second evaluation date, and the distribution of the means shifted toward the higher severity (Fig. 2).

Most of the accessions in MG VI defoliated before a second assessment was completed. However, all the accessions had reached growth stage R5 and many were in growth stage R6 when the first assessment, at 106 DAP, was completed. The mean percentage severity of the 55 accessions in MG VI was $6.7 \%$. A severity of $0 \%$ was observed on one accession, PI 587886, followed by PI 587880A and PI 587880B, 
where a severity of $0.2 \%$ was observed. PI 605781E, PI 3079620, PI 615437, and PI 594740A had mean percentage severities of $0.5,0.7,0.8$, and $0.9 \%$, respectively. Six additional accessions had percentages of $1.8 \%$ or less, and an additional 14 accessions had severities that ranged from 2.0 to 4.1\%; all were similar to PI 587886 (Table 3). There were no accessions where RB lesions were observed in more than two replications. However, RB lesions were observed in one or two replications of five accessions, and sporulation levels of 1.0 were observed with PI 549740, while the sporulation levels of the remaining accessions were 5.0.
The mean severity for the 44 accessions in MG VII at 129 DAP was $6.6 \%$ (Fig. 2). One accession, PI 587905, had a severity of $0.5 \%$ when evaluated at 129 DAP (Table 3). At 129 DAP, a severity of $1.8 \%$ was observed with PI 566989A, PI 549172A, and PI 507002, followed by PI 200492 and PI 417115 with severities of 2.2 and $2.7 \%$. A severity of $3.8 \%$ was observed with PI 578306B, PI 230970, and PI 587767B at 129 DAP. Thirteen accessions had mean severities less than $1.8 \%$ when evaluated at 106 DAP, but were either defoliated or had severities greater than $3.8 \%$ when evaluated at 129 DAP. Sixteen accessions defoliated prior to the second assessment date.
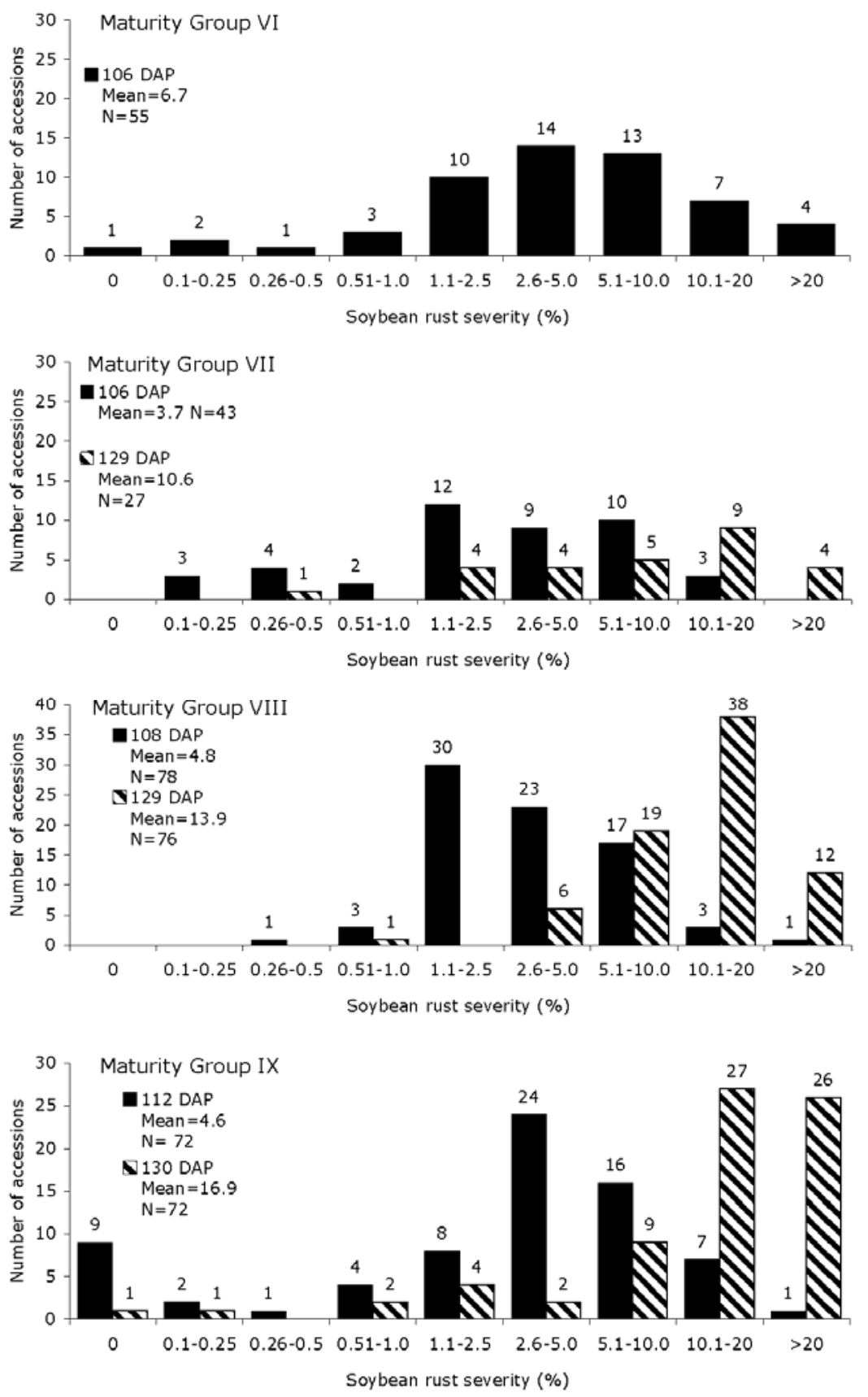

Fig. 2. Distribution of mean soybean rust severities for the accessions in maturity groups VI, VII, VIII, and IX evaluated in March 2006 from a field trial conducted at Centro Regional de Investigación Agrícola, Capitán Miranda, Itapúa, Paraguay. Maturity groups were evaluated at different days after planting (DAP), and were of different sizes $(\mathrm{N})$.

$\mathrm{RB}$ lesions were observed in three replications of PI 230970, PI 423923, PI 507259, and PI 587905 with sporulation levels of $2.5,2.7,2.3$, and $0.7 \%$, respectively. Among 12 accessions where RB lesions were observed in one or two replications, PI 417115, PI 468972, PI 567046C, and PI $605781 \mathrm{C}$ had sporulation levels of 1.0 to 2.0, while sporulation levels of 2.5 to 3.0 were observed with PI 166028, PI 423923, and PI 628898. Sporulation levels of 3.5 to 5.0 were observed with the remaining accessions.

The mean severity for the 78 accessions in MG VIII at 129 DAP was $6.6 \%$ (Fig. 2). A severity of $0.9 \%$ was observed with PI 605779E, at 129 DAP (Table 3). Eight additional accessions had severities that ranged between 3.8 and $5.6 \%$ at 129 DAP. $\mathrm{RB}$ lesions were observed on three replications of PI 416819A, PI 416778, and PI 605772 with sporulation levels of $2.3,3.7$, and 3.3, respectively. Among 19 accessions where RB lesions were observed in 1 or 2 replications, PI 203398, PI 200455, PI 567046A, PI567003A, PI 567056A, and PI 594756 had sporulation levels of 1.0 to 2.0, while sporulation levels of 2.5 to 3.0 were observed with PI 200516, PI 417126, PI 417208, and PI 587873. Sporulation levels of 3.5 to 5.0 were observed with the remaining accessions.

The mean severity for the 72 accessions in MG IX at 130 DAP was $16.9 \%$. Severities less than $0.8 \%$ were observed with PI 594754, PI 605833, and PI 567104B, with severities of $0.1,0.1$, and $0.7 \%$, respectively, when evaluated at 130 DAP. Severities between 0.9 and $1.8 \%$ were observed with PI 567102B, PI 594767B, and PI 567099A, with severities of $0.9,1.2$, and $1.8 \%$, respectively. Severities between 1.9 and $3.8 \%$ were observed with PI 594767A, PI 566964A, PI 549760A, and PI 567131B with severities of $2.4,2.5,2.6$, and $2.8 \%$, respectively. When evaluated at 112 DAP, a severity of $0 \%$ was observed with PI 594754, PI 605833, PI 567104B, PI 567102B, PI 567099A, PI 594767A, PI 566964A, and PI 549760A. Additionally, a severity of $0 \%$ was observed with PI $567145 \mathrm{C}$ at 112 DAP, but a severity of 9.3\% was observed at 130 DAP. RB lesions were observed on three replications of PI 423972, PI 594733, PI 594760B, and PI 605823 with sporulation levels of 1.0 , 3.0, 1.3, and 1.0, respectively. Among the 23 accessions where RB lesions were observed in one or two replications, sporulation levels of 1.0 to 2.0 were observed with PI 340898A, PI 417089A, PI 567102B, PI 567099A, PI 567104C, PI 567131B, PI 567139A, PI 567146A, PI 594767A, PI 594767B, and PI 594839B, while sporulation levels of 2.5 to 3.0 were observed with PI 205901B, PI 416825B, and PI 567053. Sporulation levels of 3.5 to 5.0 were observed with the remaining accessions.

Greenhouse and field evaluation of $\mathbf{1 0}$ selected accessions. In the greenhouse 
seedling experiment, all 10 of the selected accessions had severities of $0.2 \%$, indicating there were fewer than 30 lesions per leaflet (Table 4). RB lesions with little or no sporulation (sporulation levels were either 1.0 or 2.0 ) were observed with all 10 accessions. The severity and sporulation ratings of the six plants evaluated for each accession did not differ, and no statistical analysis was performed with data from the nonreplicated greenhouse experiment. The susceptible cvs. Pua 'e and Camila 6.4 had fully sporulating TAN lesions with severities greater than $7.5 \%$.

PI 605779E was not evaluated in the 10 January 2007 planting, as the seed did not germinate. PI 549754, PI 549760B, and PI $567145 \mathrm{C}$ were not planted on 10 December 2006 and 10 January 2007, as all available seed was planted on 1 November 2006.

When assessed in the 1 November 2006 and 10 December 2006 planting dates, soybean rust severity ratings of the 10 accessions ranged from 0 to $0.3 \%$, compared to severities of $30.0 \%$ for the susceptible checks (Table 4). In the 10 January 2007 planting, severities of 0 and $7.5 \%$ were observed in the two replications of PI $594767 \mathrm{~A}$, and a severity of $1.8 \%$ was observed with PI 549723. RB lesions were observed on all 10 accessions, but the sporulation levels with the RB lesions differed by accession. RB lesions with no sporulation were observed on PI 594754, whereas sporulation levels of 4.0 or more were observed on PI 594723 and PI 605779E. RB lesions with sporulation levels of 2.0 to 3.0 were observed on the remaining seven accessions. A mixed reaction, both RB and TAN lesions on the same leaflet, was observed on five of the accessions in the 1 November 2006 planting date. Sporulation levels less than 2.0 were observed with PI 567099A, PI 567102B, PI 567145C, and PI 594760B, but sporulation levels of 5.0 were observed with PI 594723. On all five accessions, the sporulation level within the TAN lesions was 5.0.

In the 10 December 2006 and 10 January 2007 plantings, RB lesions with low levels of sporulation were observed in one replication of PI 567099A, PI 567102B, and PI 587880A, while fully sporulating TAN lesions were observed in the other replication (Table 4). Soybean rust severity ratings were low in both replications. In the 10 January 2007 planting, the two replications of PI 594767A differed in lesion type, sporulation level, and severity ratings. A severity of $0 \%$ was observed in the midcanopy with nonsporulating RB lesions present in the lower canopy of one replication compared to a severity of $7.5 \%$ with fully sporulating TAN lesions in the other replication. In the 10 January 2007 planting of PI 594723, RB lesions were observed in both replications, but sporulation levels differed, 1.0 in one replication and 5.0 in the other. However, the severities were similar in the two replications, 0.8 and $1.8 \%$. No statistical analysis was performed with sporulation data from the field assessments since RB, TAN, and MX lesion types were observed within individual accessions.

\section{DISCUSSION}

Adult plants of 530 soybean accessions were evaluated in replicated trials in the field at CRIA in Capitán Miranda, Itapúa, Paraguay during the 2005-06 growing season for resistance to $P$. pachyrhizi. These 530 accessions are a subset of the 805 accessions selected in greenhouse evaluations in the United States (14) and included the accessions from MG III through MG IX, the maturity groups that could be effectively evaluated in a field trial in Paraguay. Of the 530 accessions that were evaluated, approximately $75 \%$ had soybean rust severity ratings greater

Table 4. Soybean rust severity, lesion type and sporulation level of 10 accessions with severity ratings less than $0.1 \%$ in first assessment date of adult plant field trial at Centro Regional de Investigación Agrícola, Capitán Miranda, Itapúa, Paraguay during the 2005-06 growing season when re-evaluated in greenhouse and field experiments during the 2006-07 growing season

\begin{tabular}{|c|c|c|c|c|c|c|c|c|c|c|c|c|c|}
\hline \multirow[b]{3}{*}{ Accession } & \multirow[b]{3}{*}{ MG } & & & & \multicolumn{9}{|c|}{ Field evaluation during 2006-07 growing season ${ }^{a}$} \\
\hline & & \multicolumn{3}{|c|}{ Greenhouse evaluation $^{a}$} & \multicolumn{3}{|c|}{1 Nov 2006 planting ${ }^{b}$} & \multicolumn{3}{|c|}{10 Dec 2006 planting ${ }^{b}$} & \multicolumn{3}{|c|}{10 Jan 2007 planting ${ }^{b}$} \\
\hline & & $\begin{array}{c}\text { Severity } \\
(\%)^{\mathbf{c}}\end{array}$ & $\begin{array}{l}\text { Lesion } \\
\text { type }^{d}\end{array}$ & $\begin{array}{l}\text { Sporu- } \\
\text { lation }^{\mathrm{e}}\end{array}$ & $\begin{array}{c}\text { Severity } \\
(\%)^{\mathrm{c}}\end{array}$ & $\begin{array}{c}\text { Lesion } \\
\text { type }^{\mathrm{d}}\end{array}$ & $\begin{array}{l}\text { Sporu- } \\
\text { lation }^{\mathrm{e}}\end{array}$ & $\begin{array}{c}\text { Severity } \\
(\%)^{\mathbf{c}}\end{array}$ & $\begin{array}{l}\text { Lesion } \\
\text { type }^{\mathrm{d}}\end{array}$ & $\begin{array}{l}\text { Sporu- } \\
\text { lation }^{\text {e }}\end{array}$ & $\begin{array}{c}\text { Severity } \\
(\%)^{\mathbf{c}}\end{array}$ & $\begin{array}{l}\text { Lesion } \\
\text { type }^{\mathrm{d}}\end{array}$ & $\begin{array}{l}\text { Sporu- } \\
\text { lation }^{\mathrm{e}}\end{array}$ \\
\hline PI 587886 & VI & 0.2 & $\mathrm{RB}$ & 1.0 & 0.2 & $\mathrm{RB}$ & 2.0 & 0.2 & $\mathrm{RB}$ & 3.0 & 0.3 & $\mathrm{RB}$ & 2.0 \\
\hline PI 587880A & VI & 0.2 & $\mathrm{RB}$ & 1.0 & 0.1 & $\mathrm{RB}$ & 3.0 & 0.1 & RB/TAN & 1.0 or 5.0 & 0.0 & $\mathrm{RB}^{\mathrm{f}}$ & 1.0 \\
\hline PI 605779E & VIII & 0.2 & $\mathrm{RB}$ & 1.0 & 0.4 & $\mathrm{RB}$ & 4.0 & 0.0 & $\mathrm{RB}^{\mathrm{f}}$ & 2.0 & $\ldots{ }^{\mathrm{g}}$ &..$^{g}$ & $\ldots{ }^{\mathrm{g}}$ \\
\hline PI 594754 & IX & 0.2 & $\mathrm{RB}$ & 1.0 & 0.1 & $\mathrm{RB}$ & 1.0 & $\ldots{ }^{\mathrm{h}}$ & $\ldots^{\mathrm{h}}$ & $\ldots{ }^{h}$ & $\ldots^{\mathrm{h}}$ &.$^{\mathrm{h}}$ & $\ldots{ }^{h}$ \\
\hline PI 594760B & IX & 0.2 & RB & 2.0 & 0.2 & MX & 2.0 or 5.0 & $\ldots{ }^{\mathrm{h}}$ &.${ }^{\mathrm{h}}$ &..$^{\mathrm{h}}$ &..$^{\mathrm{h}}$ & ${ }^{\mathrm{h}}$ &.$^{\mathrm{h}}$ \\
\hline PI 594767A & IX & 0.2 & RB & 1.0 & 0.0 & $\mathrm{RB}^{\mathrm{g}}$ & 2.0 & 0.2 & $\mathrm{RB}$ & 3.0 & 0.0 or $7.5^{\mathrm{i}}$ & RB/TAN & 1.0 or 5.0 \\
\hline PI 567102B & IX & 0.2 & $\mathrm{RB}$ & 1.0 & 0.1 & MX & 2.0 or 5.0 & 0.2 & RB/TAN & 2.0 or 5.0 & 0.2 & MX & 2.0 to 4.0 \\
\hline PI 567099A & IX & 0.2 & $\mathrm{RB}$ & 1.0 & 0.1 & MX & 1.0 to 5.0 & 0.1 & $\mathrm{RB} / \mathrm{TAN}$ & 2.0 or 5.0 & 0.2 & MX & 1.0 to 5.0 \\
\hline PI 567145C & IX & 0.2 & $\mathrm{RB}$ & 2.0 & 0.3 & MX & 2.0 to 5.0 & $\ldots^{\mathrm{h}}$ & $\ldots{ }^{\mathrm{h}}$ & $\ldots{ }^{h}$ & $\ldots{ }^{h}$ & & $\ldots{ }^{\mathrm{h}}$ \\
\hline PI 594723 & IX & 0.2 & RB & 1.0 & 0.3 & MX & 5.0 & 0.1 & RB/TAN & 1.0 or 5.0 & 1.8 & $\mathrm{RB}$ & 1.0 or 5.0 \\
\hline Pua ‘e & VI & 30.0 & TAN & 5.0 & 30.0 & TAN & 5.0 & 30.0 & TAN & 5.0 & 30.0 & TAN & 5.0 \\
\hline Camila 6.4 & VI & 7.5 & TAN & 5.0 & 30.0 & TAN & 5.0 & 30.0 & TAN & 5.0 & 30.0 & TAN & 5.0 \\
\hline LSD $^{\mathrm{j}}$ & & --- & & --- & 0.2 & & --- & 0.5 & & --- & 1.1 & & --- \\
\hline
\end{tabular}

${ }^{a}$ Greenhouse evaluation consisted of six plants per accession inoculated 3 weeks after planting; individual plants were evaluated for severity, lesion type, and sporulation level 2 weeks after inoculation. Field evaluation consisted of 1-m rows from which five trifoliolates from midcanopy were evaluated.

${ }^{\mathrm{b}}$ Four replications were planted on the 1 Nov planting date; two replications each were planted on the 10 Dec and 10 Jan planting dates.

${ }^{\mathrm{c}}$ Mean soybean rust severity was calculated from a sample of three to five trifoliates collected from within the midcanopy of each replication using a 1 to 9 scale with: $1=$ no soybean rust present, $2=$ up to $0.25 \%$ of surface affected, $3=$ up to $0.5 \%$ of surface affected, $4=$ up to $1 \%$ of leaflet surface affected, $5=$ up to $2.5 \%$ of surface affected, $6=$ up to $5 \%$ of surface affected, $7=$ up to $10 \%$ of leaflet affected, $8=$ up to $20 \%$ of leaflet surface affected, and $9=$ over $20 \%$ of leaflet surface affected. Ratings were converted to percentages using the midpoint for each range.

${ }^{\mathrm{d}}$ Lesion type classified as the resistant reddish-brown (RB) or the susceptible tan colored (TAN). If no lesions were observed, the lesion type was classified as an immune (I). Where both RB and TAN lesions were observed on an individual leaflet, the reactions were mixed (MX). RB/TAN was listed if one rep was RB and the other TAN.

${ }^{\text {e }}$ Sporulation was evaluated visually on a 1 to 5 scale: $1=$ no sporulation, $2=$ sporulation less than $25 \%$ of a TAN lesion, $3=50 \%$ sporulation of a TAN lesion, $4=$ sporulation was $75 \%$ of a TAN lesion, and $5=$ sporulation comparable to a fully sporulating TAN lesion. When sporulation ratings differed by replication or on plants within a row, both ratings were presented.

${ }^{\mathrm{f}} \mathrm{RB}$ lesions were observed in the lower canopy, whereas severity rating was from midcanopy.

g PI 605779E did not germinate in both replications of the 10 Jan planting date.

${ }^{\mathrm{h}}$ Accession was not planted due to insufficient seed.

${ }^{i}$ Severity differed between the replications.

j Means separated by Students' LSD, $P=0.05$. No analysis was conducted with severity and sporulation data from the nonreplicated greenhouse experiment or from the sporulation data from the field experiments since there were differences in lesion type within some accessions. 
than $1.8 \%$ when evaluated as adult plants during the 2005-06 field season, even though these accessions had been selected as potential resistance sources when inoculated with a mixture of four $P$. pachyrhizi isolates, one of which was from Paraguay (13). This result may be due to several factors including differences in virulence between the $P$. pachyrhizi population in the field in Paraguay and the isolates used in the greenhouse seedling screen in the United States, single versus multiple periods of moisture and inoculation cycles in the greenhouse and field, respectively, and longer exposure of the accessions to the pathogen in the field trials. The greenhouse evaluations, although repeated and replicated, were conducted using single plants compared to three to five plants per row per evaluation in the field experiments. Additionally, these results may reflect differences in resistance between seedling and adult plants due to the presence of partial resistance traits not detected in the seedling evaluations and not identified with two severity assessments in the field experiment. The maturity of the accessions within each MG on the date of assessment also had an impact on the percentage with severities ratings greater than $1.8 \%$. If the accessions were close to maturity, the percentage of the accessions within the MG with severities greater than $1.8 \%$ increased compared to MG where the accessions were further from maturity when evaluated on the second assessment date.

In the 2005-06 field trial, RB lesions were observed in the field on several accessions including PI 567102B and PI $594760 \mathrm{~B}$, two of the accessions selected as highly resistant. However, the presence of bacterial pustule interfered with the identification of RB lesions; bacterial pustule is similar in appearance to nonsporulating $\mathrm{RB}$ lesions. No comparisons were made between this study and the one conducted previously in the FDWRSU greenhouse (14). However, RB lesions were observed on all 10 of the accessions evaluated in the greenhouse and 2006-07 field experiments, which was consistent with the observation of RB lesions reported for these accessions in the FDWSRU seedling evaluations (14).

PI 594754 (MG IX) was the only accession with soybean rust severity rating of $0 \%$ for both assessment dates in the 200506 field evaluation. The resistance was confirmed in the subsequent greenhouse and the field evaluations, where low severity and nonsporulating RB lesions were observed. There were several accessions with severities less than $1.8 \%$ for both assessment dates in the 2005-06 field evaluation. Included in this group were: PI 587905 (MG VII), PI 567099A, PI 567102B (MG IX), PI 594760B (MG IX), PI 594754 (MG IX), and PI 594767A (MG IX), all of which had a severity of $0 \%$, no soybean rust observed, in the first assess- ment date. The resistance of these accessions was confirmed in the subsequent greenhouse and the field evaluations, where low severities and RB lesions with low sporulation levels were observed.

A soybean rust severity of $0 \%$ was observed with PI 587886 (MG VI) in the single assessment taken in the 2005-06 field evaluation. The greenhouse seedling inoculation and the 2006-07 field evaluations confirmed the low severity ( 0.0 to $0.3 \%$ ) and the presence of RB lesions with low sporulation levels (1.0 to 3.0).

Virulence was found to be heterogeneous in collections obtained within individual fields in Asia $(17,21)$. The observation of mixed reactions, RB and TAN lesions on the same trifoliate in the field in Paraguay, indicated that the pathogen population may be heterogeneous for virulence. In greenhouse experiments when the known sources of resistance were inoculated with homogenous isolates, the lesions were either TAN or RB; a mixture of lesion types was observed only when isolates were mixed $(1,4,7)$.

The accessions with mixtures of RB and TAN lesions on individual trifoliolates in the 10 November 2006 planting, were also the accessions with RB lesions in one replication but not the other replication in the second and third planting dates of the 2006-07 trial. The observation of RB lesions in one replication but not the other in the later plantings may be due to seed mixtures, the presence of volunteer soybean plants in the field, or planting errors. However, there were no obvious differences in plant morphology between the replications, and TAN or RB lesions were observed on all trifoliolates from all plants sampled within each replication. Since severity remained low, less that $0.8 \%$, for most of the 10 selected accessions, the presence of a few RB lesions may have been overlooked in the field evaluation.

The two accessions identified as immune in the 2005-06 field trial, PI 594754 and PI 587886, were found to be highly resistant in the subsequent greenhouse and field assessments, but need to be evaluated against other $P$. pachyrhizi isolates or field populations to confirm their resistance, as neither was immune as seedlings (14). In each MG, there were accessions with low or intermediate severities, less than $1.8 \%$, on both evaluation dates. These accessions may be potential sources of partial resistance that limit the development of $P$. pachyrhizi. Further evaluation of these accessions in both field and greenhouse experiments is needed to identify the traits that contribute to partial resistance, determine if the resistance is race specific, and determine the range of $P$. pachyrhizi isolates against which the resistance will be effective.

This is the first report of resistance to $P$. pachyrhizi evaluated in adult plants from a 530 line subset of the 805 soybean acces- sions previously selected in seedling evaluations in the United States as potential sources of resistance (14). PI 549723, PI 549754, PI 594760B, PI 594767, PI 567099A, PI 567102B, PI 567145C, PI 587880A, PI 587886, and PI 605779E were selected as resistant, severities less than $0.2 \%$, from the first assessment made in the 2005-06 growing season. The low soybean rust severity and presence of RB lesions with reduced sporulation was observed in subsequent greenhouse and field evaluations in the 2006-07 season and confirmed the resistance of these accessions. These accessions with low adult plant severities may be new sources of resistance to $P$. pachyrhizi.

\section{ACKNOWLEDGMENTS}

We are grateful to R. L. Nelson and his staff (USDA Soybean Germplasm Collection Center, Urbana, IL) for providing soybean seed used in this study. We also wish to thank the field crew in Paraguay (Centro Regional de Investigación Agrícola, Capitán Miranda, Itapúa, Paraguay) for managing the field. This research was funded in part by the United Soybean Board as USB Projects 229, 3217, and 4217 and supports the goals of the USDA National Strategic Plan for the Coordination and Integration of Soybean Rust Research.

\section{LITERATURE CITED}

1. Bonde, M. R., Nester, S. E., Austin, C. N., Stone, C. L., Frederick, R. D., Hartman, G. L., and Miles, M. R. 2006. Evaluation of virulence of Phakopsora pachyrhizi and P. meibomiae isolates. Plant Dis. 90:708-716.

2. Bromfield, K. R. 1984. Soybean Rust. Monogr. 11. American Phytopathological Society, St Paul, MN.

3. Bromfield, K. R., and Hartwig, E. E. 1980 Resistance to soybean rust [Phakopsora pachyrhizi] and mode of inheritance. Crop Sci. 20:254-255.

4. Bromfield, K. R., Melching, J. S., and Kingsolver, C. H. 1980. Virulence and aggressiveness of Phakopsora pachyrhizi isolates causing soybean rust. Phytopathology 70:17-21.

5. Fehr, W. R., Caviness, C. E., Burmood, D. T., and Pennington, J. S. 1971. Stage of development descriptions for soybeans, Glycine max (L.) Merr. Crop Sci. 11:929-931

6. Hartman, G. L. 1995. Highlights of soybean rust research at the Asian Vegetable Research and Development Center. Pages 19-28 in: Proceedings of the Soybean Rust Workshop, 9-11 Aug. 1995. J. B. Sinclair and G. L. Hartman, eds. College of Agricultural, Consumer, and Environmental Sciences, National Soybean Research Laboratory, Urbana, IL.

7. Hartman, G. L., Bonde, M. R., Miles, M. R. and Frederick, R. D. 2004. Variation of Phakopsora pachyrhizi isolates on soybean. Pages 440-446 in: Proceedings of VII World Soybean Research Conference, IV International Soybean Processing and Utilization Conference, III Congresso Mundial de Soja (Brazilian Soybean Conference). F. Moscardi, C. B. Hoffman-Campo, O. Ferreira Saraiva, P. R. Galerani, F. C. Krzyzanowski, and M. C. CarrãoPanizzi, eds. Emprapa Soja, Londrina, Brazil.

8. Hartman, G. L., Miles, M. R., and Frederick, R. D. 2005. Breeding for resistance to soybean rust. Plant Dis. 89:664-666.

9. Hartwig, E. E. 1986. Identification of a fourth major gene conferring resistance to soybean rust. Crop Sci. 26:1135-1136.

10. Hartwig, E. E., and Bromfield, K. R. 1983. Relationships among three genes conferring specific resistance to rust in soybeans. Crop 
Sci. 23:237-239.

11. Marchetti, M. A., Uecker, F. A., and Bromfield, K. R. 1975. Uredial development of Phakopsora pachyrhizi in soybeans. Phytopathology 65:822-823.

12. McLean, R., and Byth, D. E. 1980. Inheritance of resistance to rust (Phakopsora pachyrhizi) in soybean. Aust. J. Agric. Res. 31:951-956.

13. Miles, M. R., Frederick, R. D., and Hartman, G. L. 2003. Soybean rust: Is the U.S. crop at risk? APSnet Feature Story, June 2003. American Phytopathological Society, St. Paul, MN.

14. Miles, M. R., Frederick, R. D., and Hartman, G. L. 2006. Evaluation of soybean germplasm for resistance to Phakopsora pachyrhizi. Plant Health Progress: doi:10.1094.PHP2006=0104-01-RS

15. Miles, M. R., Rosenblatt, I., Traynor, P., and Hartman, G. L. 2005. Severity assessment for soybean rust. Proceedings of the National
Soybean Rust Symposium, Nov. 14-16, 2005, Nashville, TN. Plant Management Network. Online publication.

16. Morel, W., Scheid, N., Amarilla, V., and Cubilla, L. E. 2004. Soybean rust in Paraguay, evolution in the past three years. Pages 361364 in: Proceedings of VII World Soybean Research Conference, IV International Soybean Processing and Utilization Conference, III Congresso Mundial de Soja (Brazilian Soybean Conference). F. Moscardi, C. B. Hoffman-Campo, O. Ferreira Saraiva, P. R. Galerani, F. C. Krzyzanowski, and M. C. CarrãoPanizzi, eds. Emprapa Soja, Londrina, Brazil.

17. Poonpolgul, S., and Surin, P. 1985. Physiological races of soybean rust in Thailand. Thai Phytopathol. 5:119-120.

18. Schneider, R. W., Hollier, C. A., Whitam, H. K., Palm, M. E., McKemy, J. M., Hernandez, J. R., Levy, L., and DeVries-Paterson, R. 2005. First report of soybean rust caused by Phakop- sora pachyrhizi in the continental United States. Plant Dis. 89:774.

19. Singh, B. B., and Thapliyal, P. N. 1977. Breeding for resistance to soybean rust in India. Pages 62-65 in: Rust of Soybeans, The Problem and Research Needs. R. E. Ford and J. B Sinclar, eds. Int. Agric. Pub., INTSOY Ser. No. 12, University of Illinois, Urbana.

20. Wang, T. C., and Hartman, G. L. 1992. Epidemiology of soybean rust and breeding for host resistance. Plant Prot. Bull. (Taiwan) 34:109 124.

21. Yee, C. C. 1983. Physiological races of Phakopsora pachyrhizi in Taiwan. J. Agric. Res. China 32:69-74.

22. Yorinori, J. T., Paiva, W. M., Frederick, R. D., Costamilan, L. M., Bertagnolli, P. F., Hartman, G. E., Godoy, C. V., and Nunes, J., Jr. 2005. Epidemics of soybean rust (Phakopsora pachyrhizi) in Brazil and Paraguay from 2001 to 2003. Plant Dis. 89:675-677. 